\title{
Women Communication in Albanian Politics From 2005 and in Following Years
}

\author{
Miranda Cili \\ European University of Tirana, Tirana, Albania
}

\begin{abstract}
Communication is a process of relation. It is well-known that to communicate does not mean only to give a message but also to enter in a relationship, in which all perform their own roles and try even to create their own image. In this relationship, public (political) communication plays a special role, which in Albania is generally rude and aggressive. Political situation referring to communication is almost all the time in a kind of pressure especially during the local elections and parliamentary ones too. Very strong and harsh terms are used. In the last years, after 2005, political situation has shown the political language terms critters by telling which speaking manner has been related to both sides, the right and the left, on the conflict between both parts has been presentable all the time and who has identified most the lack of being clear. Political sides in Albania use special language instruments adding patriarchal and aggressive elements during their debates and discussions. Taking this role for a woman, it means to have a lot of courage. She has to take the risk that everything has the possibility to take place; she may be insulted and may be told offensive words. Unfortunately, verbal political culture of politicians (men) is not the one we all want and this shows their weakness in their discussions by using insults instead of arguments. Albania has been noticed a wild communication of women in politics after 2005 and in the following years, a characteristic which does not fit them, as women's such behavior may justify that their presence in political activities may not feminize their role in such masculism politics as the Albanian one, in the battle for survival may have been unfeminine by themselves. The usage of a rude dictionary has been seen as an effective manner for creating authority with the people who around and interact with you. As a conclusion, women cannot "smooth" the nature of political behavior.
\end{abstract}

Keywords: political parties, political communication, political language, masculism, women in politics, feminism

\section{Introduction}

Communication is a part of every activity and a part of people's daily life too. Based on how important the communication is in people's life, it is inalienable to think that communication is unavoidable in both life of organization and in leadership process too. Communication is important not only in the leadership functions, but also in realizing all social functions with success. With political communication, people will understand not only verbal or written declarations, but also visual components as wearing, make-up, and hairstyle, so that with all these elements of communication, it can be said that these create an "image" or a political identity (McNair, 1995). A good political communication is important not only for high level political functionaries in a party, but also important and significant as the foundation for achieving its objectives of a party, by being

Miranda Cili, Ph.D. candidate, European University of Tirana. 
communicable with people in the future elections in Albania. To understand the political communication (language of power or the language of those who fight for power), that is a communication of action and that is referred to what Edelman (1985) has called symbolical politics, we should consider the political reality, which is called by Edelman as double reality (instrumental dimension and the expressive one).

The public political communication has been dominated more from the emotional arguments, which has made it hard to transmit the written political message between parts. Furthermore, sometimes, it has transmitted the wrong message. It seems that public political communication is used to use rude arguments in a striking and shocking language against the political opponent, a manner of speaking which comes directly from the mouth of those who are government officials actually. But, the professionals of political communication know that the "abc" of political communication is that the politician should think twice before saying a word, because this word may take not only the meaning of what the speaker says, but also the meaning of the one who hears these words (Fuga, 2005). Since the elections from June 2009 to 2013, the language spoken between the deputies in government and those in opposite has been rude. Both parts have used epithets. Those epithets, if used by ordinary people in their daily life, would have been very offended. Generally, in massive population, these insults do not pass without physical confrontation among them, especially between emotional people. As in politics, addressing a lot of accusation against moral, family members are turned now as usual phenomena. It seems that it does not bother anyone because it is considered as part of doing politics and your duty too. In fact, anyone who comes in the public space to express thoughts should take in consideration the risk of being offended because of the manner of speaking or thinking (Fuga, 2010).

\section{Political Language Today}

Political language is a specific one, which has its rules, its codes, and its temperament of transmission in public. The range of speaking in politics is very diversified. Speaking a little and saying a lot; speaking a lot and saying nothing; confessing; telling things by hiding the essence; making high praising by hiding the anger; smiling by camouflaging the hate; complicating the phrase by hiding the thought; building half-truths; and by appearing transparent, all these are political instruments of expressing.

Infinite style (incomplete style) has become an evidential feature of Albanian politicians, which has turned the evasive speaking in their goal. The worst is that some features in the way of speaking have been practiced as a style of acting. In other words, there are some politicians who work the same way they communicate. Referring to writing, it is hard to tell the authentic style of theirs, because integral materials published by politicians are very little. Verbal reality of Albanian politics is built frequently on weak concepts, unclear and unstable. It neither has clear thoughts, nor complete and well-formed, and as a result, surely this will lead to confusion ideas, terms, and semantic evolution.

Albanian politics has elaborated a hermetical speaking style in order to protect it from confrontation and responsibilities, so that the political battle between the main parties in the lack of identical true program and clear position orientation has resulted in fight of closed phrases, jokes, irony, and allegory, which really have no relation with the essence of doing politics, but have a big emotional impact in electorate. It seems like that a silent deal is written between professional politicians and electorate. Politics produces empty phrases and electorate values, not the essence of discussion, not what the politicians say, but the way they say it, who made the most elegant irony, who made the most effective joke. Orwell (1946) in the middle of the 20th century characterized the formal language of politician in a brilliant manner as "Words that are gathered together as 
horses of cavalry hear the call of horn in the same line and always the same lines ready for march."

Different authors agree that political language is the main tool of doing politics. It is used depending on certain politic interests and may be clear or unclear depending on how true they are. The latest situation of politics in Albania has showed the features of political language, a language which has always been connected with the left or the right hand (even though in certain cases, there has been strong tied political interests), the conflict between both parties has continuously been presentable and what has identified is the lack of clearness.

\section{Women Communication in Politics}

Politics, language, and thinking have been often the main subjects in Orwell's works. Staying away from politics is impossible. All things are connected to politics and the politics itself is all a lie, a mountain filled with lies, folly, and hate. When the usual atmosphere generates, the language suffers. Language of corruption, as Orwell (1946) says, comes out from economical and political reasons.

Referring to communication, the political situation is in a kind of pressure all the time and even more in election times not only the parliamentary elections, but also in the local ones. Very tough terms and rude words are used.

What has been observed in political communication analysis of female politicians is that except speaking, they use also the body language, like facial mimicry and other gestures which are often borrowed from the leaders who govern actually (Dhima, 2013). Obligated to obey their chiefs (party leaders), women in politics have changed the way they speak in public. They are not any more characterized by fragility or the soft tonality. In order to amortize the conflict, they are turned in political "suicide."

Actually, in Albania parliament or in press conferences, tough phrases, strong accuses, and the smoothest vocabularies are used by female politicians, especially when they speak against each other. Women cannot realize the "softness" of politics. They could not even bring some "femininity"; but the worst was that they were "unfeminine." Women are ordered in front of each other and the accuses against the other political camp are prepared usually by the other women in the opposite camp. Female politicians are those who try to imitate men. Moreover, intellectual women in politics or in media are wilder than a considerable part of men.

The couples inside the Democratic Party and Social Party, as Topalli-Ligori, Pernaska-Felaj, Doda-Shkreli,Vokshi-Xhacka, Bregu-Kodheli, etc., have often been in the skies of smooth and strong debates. In these debates, have always been presentable the insults oriented to the proper gender, even when their sentences start with the phrases "... as a woman and as a mother..." (Vangjeli, 2010).

On the top list stands surely the chairman of parliament, Ms. Jozefina Topalli. This is because of her presence in public, her nature and her tonality have always been in high frequency and masculine. All have seen respected women who speak with impropriate tones and who accuse their opponents in political life for their private life. Despite their soft voice pronunciation, words have been always tough. It is known that what is articulated from their mouth is not their real thought, but a duty given by their proper leaders, who throw mud on the rivals. Why not for earning the television time and the press pages.

In this aspect, even the media has played its role in the change of communication because the political parties have priority making known of the problematic and conflicts in the media.

What it hurts is that (even though for a long time, it seems all normal as normal that the contrary would surprise us) female elites cannot make the difference. In this point, not only for political cases, but also nor for personal principles "fight." It never has been heard that a deputy opposes her own party leader. 
Nor when they use offensive vocabulary, nor in the name of dividing the power and balancing the power (check and balance), nor in the name of ethics (that woman that has a family just like you). In contrary, they attack with the same hate even with the same words (to pamper the "chief" sensibility).

\section{Prepared Speeches}

Anyone may see the nowadays parliament as vulnerable, conflict-promoter, without ideas, without constructive debate, without democracy, a big endless generator of defamation, and a place where they treat as hall where no responsibility is taken in front of public (Blushi, 2011). By Aristotle, a speech is not enough to contain convincing arguments, even the speaker seemed credible. Many impressions from the audience are created before the speaker starts speaking. As advised more than a century ago by the poet Ralph Waldo Emerson: "Use any language you want but, you'll never say more than except that what you are" (Dhima, 2013).

Probably, nowadays, politics would consider attack and fight referring Stalinist principals: "Attack is the best weapon and safer for the victory." Ordered speeches are another "black mark" of tough communication of women in politics. Oftentimes, women deputies read speeches that do not even understand, let alone the public. The parliamentary pulpit is transformed in a pulpit of political parties. As male politicians, women also "express poison" in their speeches.

\section{Conclusion}

Political arena has historically been a domain of men not only in Albania, but also all around the world. As a result, women find it difficult to develop their self-confidence to be a candidate in public posts. History of power is also a masculine history, even though during the last century, all around the world, there is a wide movement of women for being even those part of the government and this is the most natural thing in a society. Even in Albania, the attitudes are being changed and becoming more admitted toward the engagement of women in politics. Goals are considered even the organization forms of women beginning from non-profit organization up to coalition and networks. Communication is in the center of political process. Communicating is becoming a strong weapon in projection of image of political parties, government, organizational, and cooperative. Even communication is not only becoming a challenge that makes the difference among the institutions of all specters, but also among political parties, especially during the electoral campaigns, promoting the programs, visions, ideas, politics, and their recourses in a most efficient way. Political situation in this place referring the communication is in a kind of pressure even more in the periods of parliamentary or local elections. The researcher thinks that probably the use of a tough language is the right way to put the authority in the circle of people one acts and interacts every day. Political women know how difficult it is to have a bright future if they would behave in politics not in the proper way, as "housewife" obeyed, as good woman, quiet woman, or goodhearted, instead, they have to create the image of man converting in woman in a party/politics. But the conflicts like the political language are both parts of doing politics, without which a democratic state cannot exist.

\section{References}

Blushi, K. (2011). Shfytyrimi ose topallizimi i parlamentarizmit. Retrieved from http://www.ama-news.al/2011/03/shfytyrimiose-topallizimi-i-parlamentarizmit-nga-kico-blushi/

Dhima, A. (2013). Anthropology of communication: Access to the Albanian reality. Tirana: Kumi. 
Edelman, M. (1985). Political language and political reality. Political Science and Politics, 18(1), 10-19.

Fuga, A. (2005). Readings in communication. Time.

Fuga, A. (2010). Where are you going political language. Retrieved from http://www.albeu.com/opinion/artan-fuga/ku-po-shkongjuha-politike/25807/

McNair, B. (1995). An introduction to political communication. London, U.K.: Taylor and Francis Group.

Orwel, G. (1946). Politics and the English language. Horizon, 13, 252-265.

Vangjeli, L. (2010). Women of the new policy-How were the pigeons falcons. Mapo Magazine. 